\title{
Eritema fixo induzido por naproxeno
}

\section{Fixed drug eruption to naproxen}

\author{
Rev Port Imunoalergologia 2019;27 (2): 165-166
}

Joana Silva', Magna Alves-Correia ${ }^{2}$

' Centro Saúde de Santo António, Funchal, SESARAM, EPE

${ }^{2}$ Unidade Imunoalergologia, Hospital Central do Funchal, SESARAM, EPE

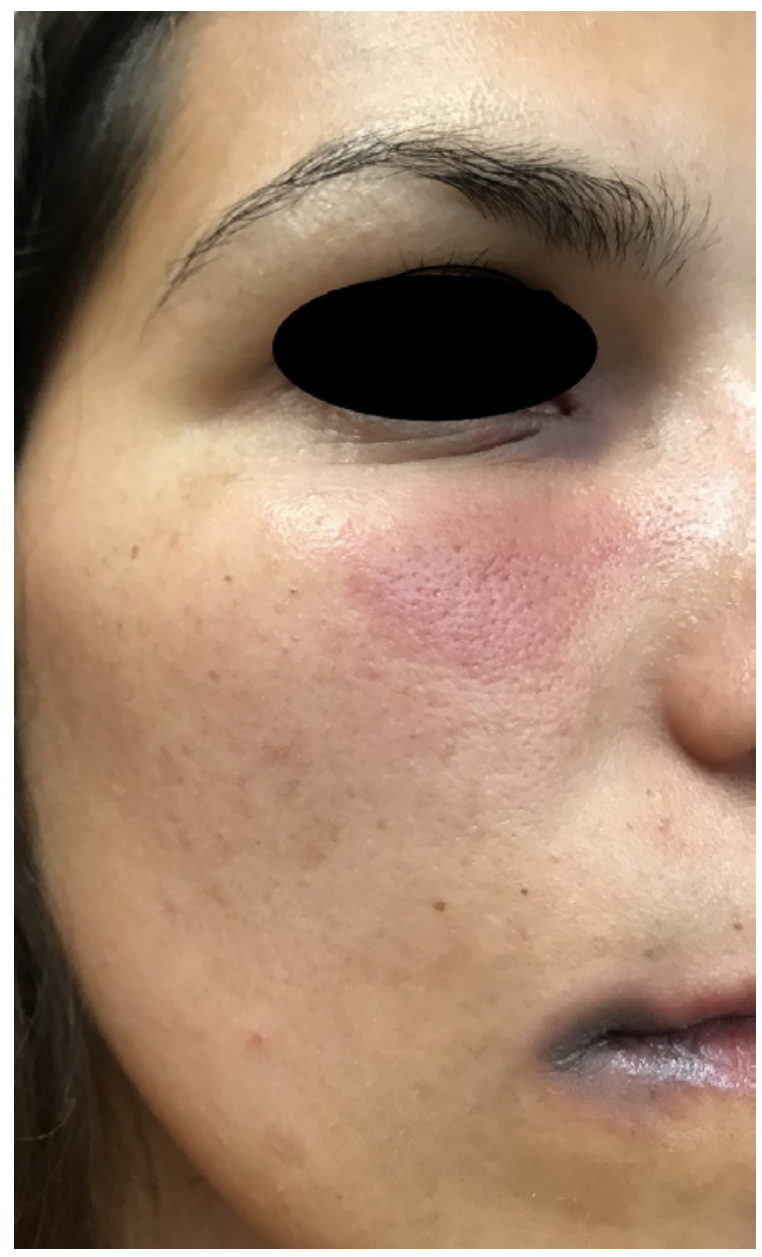




\section{COMENTÁRIO}

$\mathrm{D}$ oente do sexo feminino de 25 anos, saudável, refere erupção cutânea localizada na face, acompanhada de ardor, cerca de 6 horas após a ingestão de $500 \mathrm{mg}$ de naproxeno. Apesar de várias tomas prévias, refere nas duas últimas tomas quadro semeIhante ao atual, com hiperpigmentação residual nos locais afetados. Foi discutida a hipótese de testes epicutâneos, recusados pela doente.

O eritema fixo é um tipo de toxidermia que surge até 24 horas após a exposição a um fármaco, tendo como característica a presença de lesões eritematosas ou eritemato-violáceas, acompanhadas de prurido ou ardor e que afeta predominantemente a mucosa oral, lábios ou genitais. Com exposições subsequentes ao mesmo agente, as lesões surgem exatamente nas mesmas localizações, podendo contudo surgir novas lesões. Uma hiperpigmentação pós-inflamatória pode persistir.

O diagnóstico é essencialmente clínico, no entanto, podem ser realizadas provas de provocação oral com o agente implicado ou testes epicutâneos.

Os anti-inflamatórios não esteroides, seguidos dos antibióticos, são os agentes mais implicados neste tipo de reação, sendo a suspensão do fármaco normalmente suficiente para a resolução do quadro.

\section{COMMENT}

$T$ wenty-five years-old female patient, healthy, who reported a rash on the face, accompanied by burning, about 6 hours after intake of $500 \mathrm{mg}$ naproxen. Although previous ingestion of the same drug, she referred in the last two ingestion similar clinical manifestations to the present episode, mentioning residual hyperpigmentation in the affected sites. After discussion, the hypothesis of epicutaneous tests was rejected by the patient.

Fixed erythema is a type of toxidermia that develops up to 24 hours after exposure to a drug, characterized by erythematous or erythematous-violaceous lesions, accompanied by pruritus or burning and which predominantly affects the oral mucosa, lips or genitals. With subsequent exposures to the same agent, the lesions appear exactly in the same locations, however, new lesions can arise. Post-inflammatory hyperpigmentation may persist.

The diagnosis is essentially clinical, however, oral provocation tests may be performed with the agent involved or epicutaneous tests.

Non-steroidal anti-inflammatory drugs, followed by antibiotics, are the commonest agents involved in this type of reaction, being the suspension of the drug usually sufficient to resolve the condition.

\author{
Contacto: \\ Magna Alves-Correia \\ Unidade de Imunoalergologia - Núcleo Apoio \\ ao Hospital Dr. Nélio Mendonça - Bloco A. \\ Avenida Luís de Camões, n. ${ }^{\circ} 57$ \\ 9004-5I4 Funchal - Madeira \\ E-mail: magnacorreia0I@hotmail.com
}

